\title{
Correction to: A multi-site study on the impact of an advance care planning workshop on attitudes, beliefs and behavioural intentions over a 6-month period
}

\author{
C. C. Yu ${ }^{1 *}$, E. J. Koh'1 , J. A. Low ${ }^{1,2}$, M. L. Ong ${ }^{2}$, A. G. H. Sim³ ${ }^{3}$ D. Y. Q. Hong ${ }^{3}$, R. Chong ${ }^{4}$, J. Low ${ }^{4}$ and R. Ng ${ }^{1,4,5}$
}

Correction to: BMC Med Educ 21, 298 (2021)

https://doi.org/10.1186/s12909-021-02735-3

Following publication of the original article [1], we have been informed that the author J. Low had the affiliation incorrectly assigned.

The author group has been updated above and the original article [1] has been corrected.

\footnotetext{
Author details

${ }^{1}$ Geriatric Education and Research Institute, 2 Yishun Central 2, Singapore 768024, Singapore. ${ }^{2}$ Khoo Teck Puat Hospital, Singapore, Singapore.

${ }^{3}$ Singapore General Hospital, Singapore, Singapore. ${ }^{4}$ Tan Tock Seng Hospital,

Singapore, Singapore. ${ }^{5}$ Woodlands Health Campus, Singapore, Singapore.
}

Published online: 08 July 2021

\section{Reference}

1. Yu CC, et al. A multi-site study on the impact of an advance care planning workshop on attitudes, beliefs and behavioural intentions over a 6-month period. BMC Med Educ. 2021;21:298 https://doi.org/10.1186/s12909-021-02 735-3.

The original article can be found online at https://doi.org/10.1186/s12909021-02735-3.

* Correspondence: yu.chou.chuen@geri.com.sg

${ }^{1}$ Geriatric Education and Research Institute, 2 Yishun Central 2, Singapore 768024, Singapore

Full list of author information is available at the end of the article

(c) The Author(s). 2021 Open Access This article is licensed under a Creative Commons Attribution 4.0 International License, which permits use, sharing, adaptation, distribution and reproduction in any medium or format, as long as you give appropriate credit to the original author(s) and the source, provide a link to the Creative Commons licence, and indicate if changes were made. The images or other third party material in this article are included in the article's Creative Commons licence, unless indicated otherwise in a credit line to the material. If material is not included in the article's Creative Commons licence and your intended use is not permitted by statutory regulation or exceeds the permitted use, you will need to obtain permission directly from the copyright holder. To view a copy of this licence, visit http://creativecommons.org/licenses/by/4.0/. The Creative Commons Public Domain Dedication waiver (http://creativecommons.org/publicdomain/zero/1.0/) applies to the data made available in this article, unless otherwise stated in a credit line to the data. 